\title{
Current Status and Diversity of Ophidians (Reptilia: Squamata: Serpents) in Bhopal, Madhya Pradesh, Central India
}

\author{
Amit Manhas ${ }^{1 *}$, Rajni Raina ${ }^{2}$ and Ashwani Wanganeo ${ }^{1}$ \\ ${ }^{1}$ Department of Environmental Sciences and Limnology, Barkatullah University Bhopal, \\ Madhya Pradesh, India \\ ${ }^{2}$ Department of Zoology, Government Science and Commerce (Benazir) College, \\ Bhopal, Madhya Pradesh, India \\ *Corresponding author
}

\section{A B S T R A C T}

\begin{tabular}{|c|}
\hline Key \\
\hline $\begin{array}{l}\text { Diversity, } \\
\text { Ophidians, } \\
\text { Status and Bhopa }\end{array}$ \\
\hline Article Info \\
\hline $\begin{array}{l}\text { Accepted: } \\
12 \text { April } 2017 \\
\text { Available Onlin } \\
10 \text { May } 2017\end{array}$ \\
\hline
\end{tabular}

\section{Keywords}

Diversity,

Ophidians,

Status and Bhopal.

Article Info

Accepted:

Available Online:

10 May 2017

\begin{abstract}
A survey was conducted on the status and diversity of ophidians of Bhopal between November 2015 and September 2016. Seventeen species of snakes belonging to 17 genera and 06 families (Boidae, Colubridae, Elapidae, Pythonidae, Typhlopidae and Viperidae) were recorded during this study period. Family colubridae contributed the maximum (08 species) number of species whereas family Typhlopidae contribute minimum (1 species). Ptyas mucosa and Xenochrophis piscator was found common among non-venomous snakes while the rarest was Dendrelaphis tristis and Lycodon aulicus belonging to the family Colubridae. Among venomous snakes Naja naja was observed common where Echis carinatus was found rare in present study. Mortality due to vehicular killings and with the hands of human was observed to be the main threat in the area. Although some of the species are well scheduled in wild life protection act 1972 still peoples are unaware about the protocols given. Thus we suggest awareness programs should be organized to aware local residents about the ecology and importance of these species in an ecosystem.
\end{abstract}

\section{Introduction}

Snakes are the most fearer group of reptiles in world since their appearance but the majorities of them are non-venomous and are valuable to both humans and ecosystem. They are known to be friends of farmers besides helpful in maintaining the ecological equilibrium. Snakes inhibited all over the world except some very cold regions like the Arctic Region. There are about 3,619 species of snakes were in records under 26 families all over the world (Uetz and Hošek, 2016).
While in India about 279 species of snakes comprising of 28 families have been recorded so far (Aengals et al., 2011). Though researchers had studied and documented snakes from different parts of the state but still snakes of Madhya Pradesh are poorly known especially from Bhopal. Nineteen species of snakes were reported by Pasha et al., (2000) from Pench National Park. Ingle (2002) enlisted 30 species of snakes from Malwa region of Madhya Pradesh. Chandra 
and Gajbe (2003) had recorded ocellate shield tail snake (Uropeltis Ocellate) from Pachmarhi Biosphere Reserve. Chandra and Gajbe (2005) compiled a list of 39species of snakes which belonged to 06 families from different parts of the state Madhya Pradesh. Chandra (2009) had documented 08 species of snake's belonging to 06 families from Pachmarhi biosphere reserve. Pragatheesh and Rajvanshi (2013) studied the road mortality of snakes at Nation highway -7 along the Pench National park of Madhya Pradesh and recorded 490 such incidents. Dubey and Khare, (2013) reported 12 species of reptiles which belongs to 16 families from Chhatarpur District, Madhya Pradesh. Around 31 species of snakes under 06 families (Boidae, Colubridae, Elapidae, Typhlopidea, Uropeltidae and Viperidae) have been compiled from Satpura Tiger reserve and Panchmarhi Biosphere (Fellows, 2015). In Bhopal very little attention has been given to studies related to ophidians. Manhas et al., (2015) while working on diversity of herpetofauna documented 7 species of snakes from inside the campus Barkatullah University, Bhopal. While Manhas et al., (2015) has enlisted 17 species of snakes from Bhopal region Whereas, 11 species of snakes from Barkatullah University were recorded by Manhas et al., (2016).

However no systematic study on the status of ophidians of Bhopal region is on record, so an effort was made to provide current status of these serpents with their comprehensive list.

\section{Study area}

The present investigation was carried out in Bhopal region, the capital of the Madhya Pradesh state, central India (Figure 1). It is geographical located at latitude $23^{\circ} 14^{\prime} 01^{\prime \prime} \mathrm{N}$ and longitude $77^{\circ} 23^{\prime} 366^{\prime \prime} \mathrm{E}$ having an average elevation of 527 masl (1,729 ft.). The region has irregular elevation and small hills within its restrictions viz., Idgah hills and
Shyamalahills in the northern region, Katara hills in south region and Arera hills in the central region. The climate here is humid subtropical with hot summer and a humid monsoon season where summers start in late March and go on till mid-June, the average temperature during which remains around $30^{\circ} \mathrm{C}\left(86^{\circ} \mathrm{F}\right)$, with the peak of summer in May, when it regularly exceed $40^{\circ} \mathrm{C}\left(104^{\circ} \mathrm{F}\right)$ while monsoon starts in late June and ends in late September.

\section{Materials and Methods}

The study was conducted in Bhopal between November 2015 and September 2016. The study on live snake specimens was carried out during the study period to know presence and their current status in Bhopal. No specimen was harmed during the study. Field observations were done all over day but importance was given to morning and night observations when snakes are more active than other times, to sight the snakes. Results of some opportunistic sightings of snakes have also been incorporated in the list. The whole study area was thoroughly surveyed following visual encounter survey. The snakes that were observed more than 20 times considered very common and are denoted as "VC", common (C) which were sighted 1520times, fairly common (FC) were sighted 515 times and rare $(\mathrm{R})$ which were observed 15 times. The specimens were identified on the basis of literature documented earlier and field guide books (Smith, 1943; Daniels, 2002 and Whitaker and Captain, 2004).

\section{Results and Discussion}

Seventeen species of snakes (Table 1) belonging 06 families were sighted from Bhopal during the present investigation. Among them, 01 species $(06 \%)$ belong to the family Typhlopidae, 01 species (6\%) of Pythonidae, 08 species $(47 \%)$ of Colubridae, 03 species $(17 \%)$ of Elapidae and 02 species 
(12\%) of Viperidae and 02 species (12\%) of Boidae (Figure 2). Out of all 17 species enlisted 05 species (Python molurus, Ptyas mucosa, Xenochrophis piscator, Naja naja, Ophiophagus hannah and Daboia russelii) of snakes under 04 family were protected under Sch II (Part II) whereas other 12 species were under Sch IV of Indian Wildlife Protection act, 1972 are presented in table 1.

The total recorded species from present study area contributes $43.58 \%$ of snakes compared to the Madhya Pradesh (39 species: Chandra and Gajbe, 2005), 6.09\% snakes of India (279 species: Aengals et al., 2011) and $0.53 \%$ of World (3169 species: Uetz \& Hošek, 2016).

Four species (24\%) of snakes are very common (VC), six species (35\%) are common (C), two species (12\%) are fairly common
(FC), and five species (29\%) were observed rare (R) in Bhopal region (Figure 3). Overall, Checkered Keelback (Xenochrophis piscator) followed by Ptyas mucosa were observed the most common and Lycodon aulicus followed by Dendrelaphis tristis was rarest.

Five venomous species of snakesobserved in Bhopal region out of which 03 species falls under three genera (Bungarus, Naja and Ophiophagus) belonging to the family Elapidae and two species (Daboia russelii and Echis carinatus) under family Viperidae. The species Ophiophagus hannah was observed at Van Vihar national park Bhopal. Among the venomous species of snakes Spectacled Cobra (Naja naja) was found common whereas Echis carinatus was observed rare in current study.

\section{Fig.1 Bhopal region (MP)}

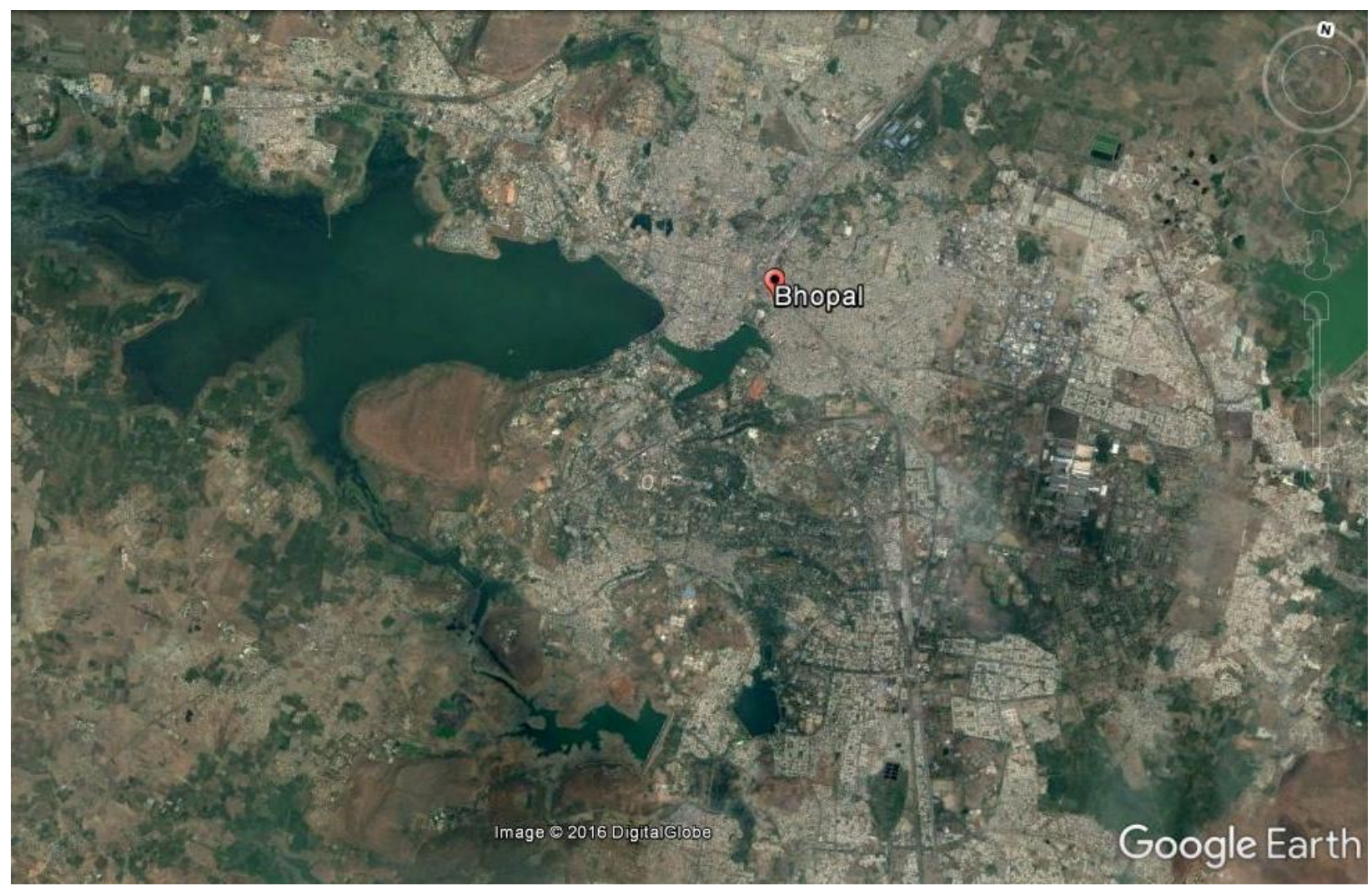




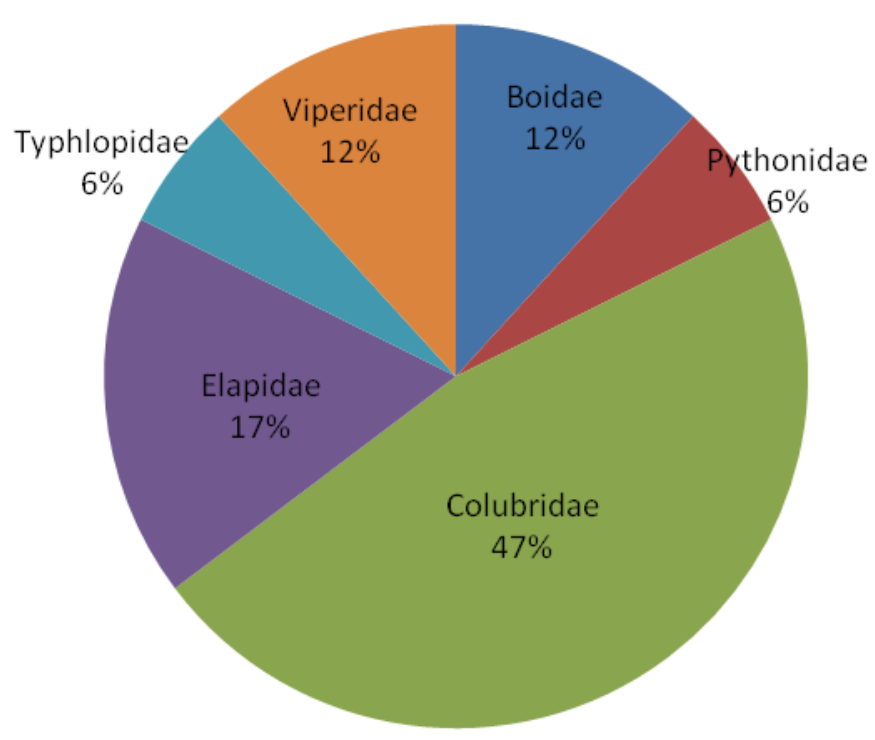

Fig.2 Percentage contribution of ophidian families during present investagation

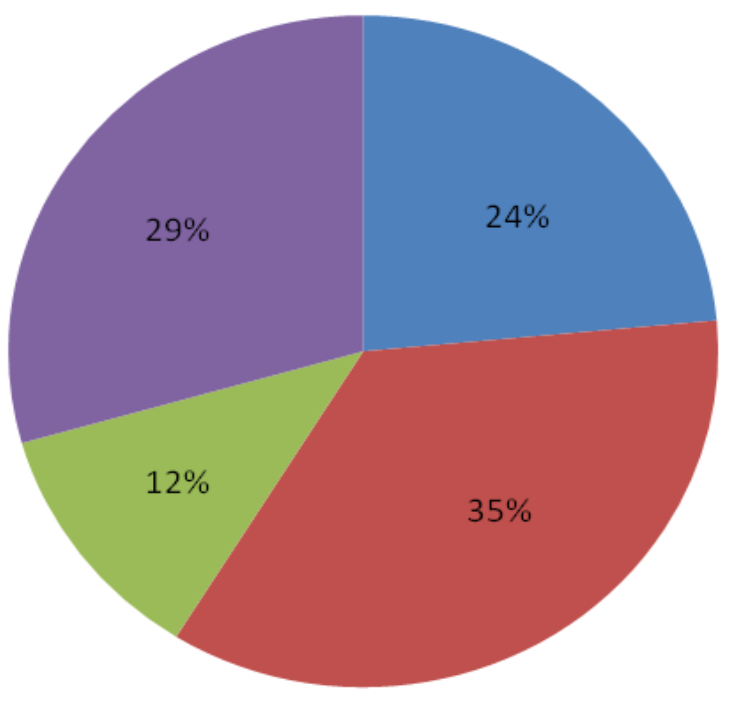

- Very common

- Common

- Fairly Common

nare

Fig. 3 Frequency in sighting of ophidians during present study 
Table.1 List of snakes observed in Bhopal (MP) along with their status (Local, WPA 1972 and IUCN 2016) India

\begin{tabular}{|c|c|c|c|c|c|c|}
\hline S.No & Family & Scientific name & Common name & $\begin{array}{l}\text { Status } \\
\text { (Bhopal) }\end{array}$ & $\begin{array}{l}\text { Schedule in } \\
\text { Protection } \\
\text { act, } 1972\end{array}$ & $\begin{array}{l}\text { IUCN } \\
\text { Status }\end{array}$ \\
\hline 1 & \multirow[t]{2}{*}{ Boidae } & Eryx conicus & Common Sand Boa & $\mathrm{C}$ & Sch IV & $\mathrm{NE}$ \\
\hline 2 & & Eryx johnii & Red Sand Boa & $\mathrm{R}$ & Sch IV & $\mathrm{NE}$ \\
\hline 3 & Pythonidae & Python molurus & Indian rock Python & $\mathrm{R}$ & $\begin{array}{l}\text { Sch I (Part } \\
\text { II) }\end{array}$ & $\mathrm{NE}$ \\
\hline 4 & & Amphiesma stolata & $\begin{array}{l}\text { Buff-Striped } \\
\text { Keelback }\end{array}$ & $\mathrm{C}$ & Sch IV & $\mathrm{NE}$ \\
\hline 5 & & $\begin{array}{l}\text { Argyrogene } \\
\text { fasciolatus }\end{array}$ & Banded Racer & $\mathrm{C}$ & Sch IV & $\mathrm{NE}$ \\
\hline 6 & & $\begin{array}{l}\text { Coelognathus } \\
\text { helena }\end{array}$ & Common trinket & FC & Sch IV & $\mathrm{NE}$ \\
\hline 7 & & Lycodon aulicus & $\begin{array}{l}\text { Common } \\
\text { Snake }\end{array}$ & $\mathrm{R}$ & Sch IV & $\mathrm{NE}$ \\
\hline 8 & Colubridae & Dendrelaphis tristis & $\begin{array}{ll}\text { Common } & \text { Bronze } \\
\text { Back } & \end{array}$ & $\mathrm{R}$ & Sch IV & $\mathrm{NE}$ \\
\hline 9 & & Oligodon amensis & Banded Kukri Snake & $\mathrm{C}$ & Sch IV & $\mathrm{NE}$ \\
\hline 10 & & Ptyas mисова & Indian Rat snake & $\mathrm{VC}$ & $\begin{array}{l}\text { Sch II (Part } \\
\text { II) }\end{array}$ & $\mathrm{NE}$ \\
\hline 11 & & $\begin{array}{l}\text { Xenochrophis } \\
\text { piscator }\end{array}$ & $\begin{array}{l}\text { Checkered Keelback } \\
\text { Water Snake }\end{array}$ & $\mathrm{VC}$ & $\begin{array}{l}\text { Sch II (Part } \\
\text { II }\end{array}$ & $\mathrm{NE}$ \\
\hline 12 & Elapidae & Bungarus caeruleus & $\begin{array}{ll}\text { Common } & \text { Indian } \\
\text { Krait } & \\
\end{array}$ & $\mathrm{C}$ & Sch IV & $\mathrm{NE}$ \\
\hline 13 & & Naja naja & Spectacled Cobra & $\mathrm{VC}$ & $\begin{array}{l}\text { Sch II (Part } \\
\text { II) }\end{array}$ & $\mathrm{NE}$ \\
\hline 14 & & $\begin{array}{l}\text { Ophiophagus } \\
\text { hannah }\end{array}$ & King Cobra & $\begin{array}{c}--- \\
\end{array}$ & $\begin{array}{l}\text { Sch II (Part } \\
\text { II) }\end{array}$ & VU \\
\hline 15 & Typhlopidae & $\begin{array}{l}\text { Ramphotyphlops } \\
\text { braminus }\end{array}$ & $\begin{array}{l}\text { Brahminy } \\
\text { snake }\end{array}$ & FC & Sch IV & $\mathrm{NE}$ \\
\hline 16 & Viperidae & Daboia russelii & Russell's Viper & $\mathrm{C}$ & $\begin{array}{l}\text { Sch II (Part } \\
\text { II) }\end{array}$ & $\mathrm{NE}$ \\
\hline 17 & & Echis carinatus & $\begin{array}{l}\text { Indian saw-scaled } \\
\text { Viper }\end{array}$ & $\mathrm{R}$ & Sch IV & $\mathrm{NE}$ \\
\hline
\end{tabular}


Out of the all species sighted, 03 species (Ptyas mucosa, Xenochrophis piscator and Amphiesma stolata) were observed to have semi-aquatic behavior whereas 05 species including Argyrogene fasciolatus, Coelognathus helena, Dendrelaphis tristis and Ptyas mucosa) was observed to have semi-arboreal and 02 species (Eryx conicus and Eryx johnii) semi-fossorial activities. Eight species of snakes were observed to be completely terrestrial in Bhopal region. Many species of snakes die due to vehicular movements mostly during the peak months of the year. During this investigation the species sighting was observed maximum in monsoon months (From Mid-June to Mid-September). Before theses months snakes were in active or been in aestivation as no species was sighted before monsoon. Because snakes are ectothermic animals and they require optimum heat to do their daily activities and in this region the summers receive very high temperature fluctuations whereas after monsoon the activity slows down up to midNovember thereafter the activities of these creatures stop completely till favorable climatic conditions. The mortality of snakes because of vehicular passage threatened snake species in this region of the state mostly during monsoons (Manhas et al., 2015).

Further investigations are required to be conducted to know the comprehensive ecology of the snakes that are residing in this portion of the country viz., Bhopal (MP). The habitat is being degraded due the destroying forests. In urban localities the species was being killed mainly because of the fear and unawareness between locals.

Furthermore, human created appliances and their settlements near forest trail and agricultural practices are also a reason for the destruction of the habitat of snakes. Thus all these reason are causing unsustainable diversity of snake species, so there is an urgent need of minimizing these tribulations for future better improvement of snake diversity in Bhopal.

\section{References}

Chandra, K. 2009. Fauna of Pachmarhi Biosphere Reserve, Conservation Area Series, 39: 117-128.

Chandra, K. and Gajbe, U.P. 2003. New record of Ocellate shield tail Uropeltis ocellata, Beddome),. Uropeltidae) from Pachmarhi Biosphere reserve, Madhya Pradesh, Cobra, 52:15-16.

Chandra, K. and Gajbe, U.P. 2005. An inventory of Herpetofauna of Madhya Pradesh and Chhattisgarh. Zoos' Prints J., 20(3): 1812-1819.

Daniel, J.C. 2002.The book of Indian Reptiles and Amphibians. Oxford University Press, New Delhi.

Dubey, A. and Khare, N. 2013. Reptile fauna of Chhatarpur district Madhya Pradesh, India. World J. Sci., 1(2): 133-144.

Fellows, S. 2015. Species Diversity of Snakes in Pachmarhi Biosphere Reserve. Ento. Ornitho. Herpeto., 4: 136. http://vindhyabachao.org/wildlife_guide lines/schedule_species_reptiles.pdf. Assessed on 22 March, 2017.

Ingle, M. 2002. Ecology and status of the ophiofauna of eight districts of Malwa region of Madhya Pradesh. Cobra, 50: 1-17.

Manhas, A., Kotwal, A., Wanganeo, R.R., Wanganeo, A. 2015. Diversity, Threats and Conservation of Herpetofauna in and around Barkatullah University, Bhopal. MP), India. Int. J. Adv. Res., 3(9): 1546-1553.

Manhas, A., Raina, R., and Wanganeo, A. 2015. Snakes of the Bhopal district, Madhya Pradesh, India with special reference to road mortality. J. Res. Biol., 5(7): 1868-1873. 
Manhas, A., Raina, R., and Wanganeo, A., 2016. An addition to the reptilian diversity of Barkatullah University campus, Bhopal, Madhya Pradesh, India. Int. J. Pure Appl. Zool., 4(4): 306-309.

Pasha, M.K.S., Areendran, G., Sankar, K. and Qureshi, Q. 2000. A preliminary checklist of snakes of Pench Tiger Reserve, Madhya Pradesh. Cobra, 40: 5-8.

Pragatheesh, A. and Rajvanshi, A. 2013. Spatial patterns and factors influencing the mortality of snakes on the national highway-7 along Pench Tiger reserve, Madhya Pradesh, India. Oecologia Australis, 17(1): 20-35.

Smith, M.A. 1943. Fauna of British India, Vol. III: Serpentes, Published by Taylor and Francis, London.

Uetz, P. \& J. Hošek. eds. 2016. The Reptile Database. Available at http://www.reptiledatabase.org/dbinfo/SpeciesStat.html. Accessed on 15 November 2016.

Whitaker, R. and Captain, A. 2004. Snakes of India-The field guide, Draco Books, Chennai, India.

\section{How to cite this article:}

Amit Manhas, Rajni Raina and Ashwani Wanganeo. 2017. Current status and Diversity of Ophidians (Reptilia: Squamata: Serpents) in Bhopal, Madhya Pradesh, central India. Int.J.Curr.Microbiol.App.Sci. 6(5): 1384-1390. doi: https://doi.org/10.20546/ijcmas.2017.605.149 